\title{
Nutrient use efficiency in interspecific hybrids of eucalypt ${ }^{1}$
}

\author{
Eficiência de utilização de nutrientes em híbridos interespecíficos de eucalipto
}

\author{
Camila Capodifoglio Rosim², Tseng Yao Hsing ${ }^{2}$ and Rinaldo Cesar de Paula*
}

\begin{abstract}
The aim of this work was to evaluate nutrient use efficiency in interspecific hybrids of eucalypt, as an aid in the development of forest breeding programs for areas with limited nutrients. To do this, five clones were evaluated at 2.25 years of age from hybrids resulting from crosses of Eucalyptus grandis x E. urophylla $(\mathrm{C} 1, \mathrm{C} 2, \mathrm{C} 3, \mathrm{C} 4$ and $\mathrm{C} 5$ ). The experimental design was of randomised blocks, with single-tree plots and 35 replications. For the study, four trees of average performance were cut down (replications) from each treatment (clone); the biomass, and content and efficiency of use of $\mathrm{N}, \mathrm{P}, \mathrm{K}, \mathrm{Ca}$ and $\mathrm{Mg}$ were determined in the wood, bark, leaves and branches. The data were submitted to analysis of variance and the F-test, and the means compared by Tukey's test at 5\% probability. It was found that the average for biomass allocation was greater $(66.2 \%)$ for the wood, followed by the branches $(13.2 \%)$, leaves (11.0\%) and bark (9.6\%). The C2 and C5 clones stood out as the most efficient in the use of P, Ca and Mg in the wood. The use of genotypes which are efficient in the use of nutrients is essential to the sustainability of forest ecosystems, reducing nutrient export in proportion to the biomass produced. Also, the recommendation of genotypes which are efficient in the use of nutrients for sites of poor soil fertility can optimise productivity in these locations.
\end{abstract}

Key words: Nutritional efficiency. Sustainability. Biomass allocation. Energy forests. Wood.

\begin{abstract}
RESUMO - Objetivou-se com este trabalho avaliar a eficiência de utilização de nutrientes em híbridos interespecíficos de eucalipto como subsídios para o desenvolvimento de programas de melhoramento florestal para áreas com limitações nutricionais. Para isso, foram avaliados cinco clones de híbridos resultantes do cruzamento de Eucalyptus grandis $x$ E. urophylla (C1, C2, C3, C4 e C5), aos 2,25 anos de idade. O delineamento experimental foi em blocos casualizados, com parcelas de uma planta ("Single Tree Plot”) e 35 repetições. Para este estudo, foram abatidas quatro árvores (repetições) de desempenho médio de cada tratamento (clone), determinando-se a biomassa e os teores e a eficiência de utilização de N, P, K, Ca e Mg no lenho, casca, folhas e galhos. Os dados foram submetidos a análises de variância e teste F e as médias comparadas pelo teste de Tukey a $5 \%$ de probabilidade. Observou-se que a alocação média de biomassa foi maior para madeira $(66,2 \%)$, seguida de galhos $(13,2 \%)$, folhas $(11,0 \%)$ e casca $(9,6 \%)$. Os clones C2 e C5 destacaramse pela maior eficiência de utilização de $\mathrm{P}, \mathrm{Ca}$ e $\mathrm{Mg}$ na madeira. O uso de genótipos eficientes na utilização de nutrientes é essencial para a sustentabilidade do ecossistema florestal, reduzindo a exportação de nutrientes proporcionalmente à biomassa produzida. Também, a recomendação de genótipos eficientes no uso de nutrientes para sítios mais pobres em fertilidade do solo poderá otimizar a produtividade nestes locais.
\end{abstract}

Palavras-chave: Eficiência nutricional. Sustentabilidade. Alocação de biomassa. Florestas energéticas. Madeira.

\footnotetext{
*Autor para correspondência

DOI: $10.5935 / 1806-6690.20160065$

${ }^{1}$ Recebido para em 02/11/2013; aprovado em 06/10/2015

Parte da Dissertação de Mestrado do primeiro autor

${ }^{2}$ Programa de Pós-Graduação em Agronomia (Genética e Melhoramento de Plantas), Faculdade de Ciências Agrárias e Veterinárias, Universidade Estadual Paulista/UNESP, Campus de Jaboticabal, Via de Acesso Prof. Paulo Donato Castellane, Km 05, Jaboticabal-SP, Brasil, 14.884-900, camiscarosim@hotmail.com, yao.htse@gmail.com

${ }^{3}$ Departamento de Produção Vegetal, Faculdade de Ciências Agrárias e Veterinárias, Universidade Estadual Paulista/UNESP, Campus de Jaboticabal, Via de Acesso Prof. Paulo Donato Castellane, Km 05, Jaboticabal-SP, Brasil, 14.884-900, rcpaula@fcav.unesp.br
} 


\section{INTRODUCTION}

The FAO report of 2010 points to an expected population growth of about $34 \%$ by 2050 ; because of this, the demand for food and for products of plant origin will tend to increase. For example, to meet the demand for food, it is estimated that agricultural production should grow $70 \%$ by the middle of this century. This will also happen with the demand for forest products, such as wood for the production of energy and pulp. Therefore, in addition to an increase in productivity, new areas should be included for agricultural production, especially in the American and African continents. A part of these areas is abandoned pasture, characterised by a low use of inputs, highlyweathered soils, a medium to high degree of acidity, toxic levels of $\mathrm{Al}$, and low nutrient availability (PARENTONI; MENDES; GUIMARAES, 2011).

In Brazil, recent years have seen an increase in the areas planted with forest, mainly of eucalypt. In 2014, for example, the area of eucalypt plantations totalled 5,558,653 ha, representing a growth of $1.6 \%$ $( \pm 130,000 \mathrm{ha})$ compared to 2013 . This increase is mainly due to the establishment of new plantations to meet the future demand of industrial projects in the paper and pulp sector (IBA, 2015).

The new areas of forest expansion in Brazil, similar to the current areas of eucalypt plantation, are of low natural fertility. Fertilisation is therefore an important and necessary practice in eucalypt plantations, and should be adjusted for each genotype so as to provide high productivity at the lowest cost and with less impact on the environment (SILVA et al., 2013), since soil correction and the addition of fertiliser is an essential practice for ensuring good productivity. Nevertheless, it is in the interest of the industry to identify genotypes with low nutritional requirements, providing productivity is not impaired. Forest breeding programs therefore, seek to find genotypes that, in addition to good productivity, display high efficiency in the absorption and use of nutrients.

Short-rotation forests, associated with the high use of local resources, have raised questions related to the ecological impact of plantations and the sustainability of timber production by the forest (STAPE; BINKLEY; RYAN, 2004), which, among other factors, is determined by the nutrient balance of the soil-plant system (SANTANA et al., 2008). Eucalypt is the most planted genus in tropical regions, but the sustainability of these plantations is a major concern of researchers, since these forests are usually established in soils of low fertility, with a large export of nutrients occurring every 6-7 years with the removal of biomass through forest harvesting (LACLAU et al., 2010). Therefore, the use of inputs is increasing in the forestry sector to balance the output of nutrients when harvesting.

In view of this, the aim of the present study was to evaluate nutrient use efficiency in young plants of eucalypt clones as an aid in the development of forest breeding programs for areas with limited nutrients.

\section{MATERIAL AND METHODS}

The experiment was set up on 27 April 2010 in an area located at $21^{\circ} 13,55^{\prime \prime} \mathrm{S}$ and $48^{\circ} 16^{\prime} 48^{\prime \prime} \mathrm{E}$, at an average altitude of $604 \mathrm{~m}$, in Jaboticabal, in the State of São Paulo, Brazil, using five commercial hybrids of eucalypt, the result of crossing Eucalyptus grandis with E. urophylla and multiplied by minicutting, hereafter referred to as clones $(\mathrm{C} 1, \mathrm{C} 2, \mathrm{C} 3, \mathrm{C} 4$ and $\mathrm{C} 5)$, as described by Mendes et al. (2013). The experimental design was of randomised blocks, in a single-tree plot design with 35 replications, at a spacing of $3.5 \times 2 \mathrm{~m}$. The local climate is type Cwa, according to the Köppen classification, with an average annual precipitation of $1425 \mathrm{~mm}$, temperature of $22.2^{\circ} \mathrm{C}$ and relative humidity of $75 \%$. The soil is classified as a typic dystrophic Red Latosol of clayey texture (SOUSA NETO et al., 2008). Soil preparation consisted of elimination of the previous crop (maize), harrowing, and furrowing. After chemical analysis of the soil (Table 1), it was found that there was no need for liming (GONÇALVES; RAIJ; GONÇALVES, 1997), and considering the type of soil and nutrient content, fertilisation, consisting of the application of $100 \mathrm{~g}$ of superphosphate per plant, was carried out when planting. Also, based on the above authors, $50 \mathrm{~g}$ of potassium chloride, $50 \mathrm{~g}$ of urea and $3 \mathrm{~g}$ of boric acid were applied per plant as top dressing 180 days after planting. At 270 days after planting, a further $80 \mathrm{~g}$ of potassium chloride and $6 \mathrm{~g}$ of borax were applied per plant.

For this study, four trees of average performance, 2.25 years of age, were sampled from each treatment (clone), determined by evaluation of the diameter at breast height $(\mathrm{DBH}$, taken at $1.30 \mathrm{~m}$ from the ground) of all the trees in the experiment. These trees were felled and the components of the trunk (bark and wood), branches and leaves were separated. The total fresh biomass of the branches and leaves was determined separately in the field, and samples of these components were removed, sealed into plastic bags and taken to the laboratory, where they were again weighed (fresh sample biomass) and subjected to drying in a forcedventilation oven at $65^{\circ} \mathrm{C}$ for $96 \mathrm{~h}$ to determine the dry weight of the samples. From these values, the total dry biomass of the leaves and branches was obtained using 
Table 1 - Results of the chemical analysis of a soil sample $(0-20 \mathrm{~cm})$ collected at the site of the experiment

\begin{tabular}{lcccccccccc}
\hline \multirow{2}{*}{$\mathrm{pH}\left(\mathrm{CaCl}_{2}\right)$} & $\mathrm{OM}$ & $\mathrm{P}$ resin & $\mathrm{K}^{+}$ & $\mathrm{Ca}^{2+}$ & $\mathrm{Mg}^{2+}$ & $\mathrm{H}+\mathrm{Al}$ & $\mathrm{Al}^{3+}$ & $\mathrm{SB}$ & $\mathrm{T}$ & $\mathrm{V}$ \\
\cline { 2 - 9 } & $\left(\mathrm{g} \mathrm{dm}^{-3}\right)$ & $\left(\mathrm{mg} \mathrm{dm}^{-3}\right)$ & & & & $\left(\mathrm{mmol}_{\mathrm{c}} \mathrm{dm}^{-3}\right)$ & & & $\%$ \\
\hline 6.5 & 17 & 29 & 1.4 & 44 & 24 & 12 & 0 & 69.0 & 81.0 & 85 \\
\hline
\end{tabular}

$\mathrm{OM}$ - organic matter; P resin - P content determined with a resin extratant; SB - Sum of bases; $\mathrm{T}$ - cation exchange capacity; V - base saturation

the rule of three. Also in the field, and after felling the trees, the length of the trunk was determined down to a minimum diameter of $4 \mathrm{~cm}$ with bark; the trunk was then cut into metres, and measurements were taken of the diameter with and without bark for strict calculation of cubage. The volume of the trunk, with and without bark, was obtained by use of Smalian's formula (SOARES; PAULA NETO; SOUZA, 2006). Samples of discs with bark were later removed from the DBH position and the base $(0 \%)$, and at $25 \%, 50 \%, 75 \%$ and $100 \%$ of the length of the trunk of each felled tree. The bark was separated from the discs, and a wedge of wood removed to determine basic density. The basic density of both the bark and the wood were determined by immersion in water, as recommended by Vital (1984). Once the basic density of the bark and the wood were obtained, and the volume of the trunk with and without bark, the dry biomass of the wood and bark were determined. To determine nutrient levels, samples of the leaves, wood, branches and bark were ground up after drying at $65{ }^{\circ} \mathrm{C}$ to constant weight, with each tree (replication) giving rise to duplicates, in the case of determining the nitrogen $(\mathrm{N})$, and triplicates in determining the other nutrients.

The $\mathrm{N}$ content was obtained by the method of sulphuric acid digestion using salts as a catalyst. To quantify the phosphorus $(\mathrm{P})$, potassium $(\mathrm{K})$, calcium
(Ca) and magnesium (Mg), the ground samples were subjected to nitric-perchloric acid digestion. Metavanadate colorimetry was used to obtain the $\mathrm{P}$ content (total phosphorus) and the levels of $\mathrm{K}, \mathrm{Ca}$ and $\mathrm{Mg}$ were found by atomic absorption (MALAVOLTA; VITTI; OLIVEIRA, 1997).

From the data for nutrient content and the dry biomass of the leaves, branches, wood and bark, the nutrient use efficiency of these tree components was obtained using the Siddiqi and Glass method (1981).

The data were submitted to analysis of variance and the mean values for the clones compared by Tukey's test at 5\% probability, using the SISVAR software (FERREIRA, 2000).

\section{RESULTS AND DISCUSSION}

The C2, C4 and C5 clones produced more wood, leaf and bark biomass than the $\mathrm{C} 1$ and $\mathrm{C} 3$ clones, however, there was no difference between clones for branch biomass (Table 2). At the age of evaluation (2.25 years), mean biomass allocation was greater for wood $(66.2 \%)$, followed by branches $(13.2 \%)$, leaves $(11.0 \%)$ and bark (9.6\%). The $\mathrm{C} 2, \mathrm{C} 4$ and $\mathrm{C} 5$ clones that allocated

Table 2 - Dry biomass $\left(\mathrm{kg} \mathrm{tree}^{-1}\right)$ of leaves, wood, branches and bark in five clones of Eucalyptus grandis $x$ E. urophylla, at 2.25 years of age

\begin{tabular}{|c|c|c|c|c|}
\hline Clone & Leaves & Wood & Branches & Bark \\
\hline $\mathrm{C} 1$ & $4.1(13.3 \%) b$ & $18.6(60.4 \%) b$ & $6.0(19.5 \%)$ & $2.1(06.8 \%) b$ \\
\hline $\mathrm{C} 2$ & $5.7(10.2 \%) \mathrm{a}$ & $38.7(69.5 \%) \mathrm{a}$ & $5.5(09.9 \%)$ & $5.8(10.4 \%)$ a \\
\hline $\mathrm{C} 3$ & $3.5(10.4 \%) b$ & $20.5(60.8 \%) b$ & $6.4(19.0 \%)$ & $3.3(09.8 \%) b$ \\
\hline $\mathrm{C} 4$ & $6.0(11.7 \%) \mathrm{a}$ & $33.8(65.6 \%) \mathrm{a}$ & $6.5(12.6 \%)$ & $5.2(10.1 \%)$ a \\
\hline $\mathrm{C} 5$ & $6.2(10.5 \%) \mathrm{a}$ & $41.6(70.1 \%) \mathrm{a}$ & $6.0(10.1 \%)$ & $5.5(09.3 \%) \mathrm{a}$ \\
\hline $\mathrm{F}$ & $30.2 * *$ & $19.6^{* *}$ & $0.2^{\mathrm{ns}}$ & $21.7 * *$ \\
\hline $\mathrm{CV} \%$ & 4.6 & 8.1 & 17.6 & 8.7 \\
\hline Mean & $5.1(11.0 \%)$ & $30.6(66.2 \%)$ & $6.1(13.2 \%)$ & $4.4(09.6 \%)$ \\
\hline
\end{tabular}

Mean values followed by the same letter in a column do not differ by Tukey's test $(\mathrm{p} \geq 0.05)$; ${ }^{\text {ns }}$ and $* *$ - not significant $(\mathrm{p} \geq 0.05)$ and significant $(\mathrm{p}<0.01)$ respectively by F-test. Values in parentheses refer to percentage biomass allocation in the different compartments of the aerial part of the plant 
biomass more evenly between branches and leaves, also allocated a higher proportion of biomass to the wood. The $\mathrm{C} 1$ and $\mathrm{C} 3$ clones, with $19.5 \%$ and $19.0 \%$ biomass allocated to the branches, displayed a lower allocation to the wood (60.4\% and $60.8 \%$ respectively). On the other hand, the $\mathrm{C} 1$ clone had the lowest percentage of bark, $6.8 \%$, against $10.4 \%$ in the $\mathrm{C} 2$ clone.

Biomass allocation in different components of trees of E. grandis, at 6 years of age and a spacing of $3 \times 2 \mathrm{~m}$ in the State of Rio de Janeiro, was $3.87 \%$ for the leaves, $5.26 \%$ for the branches, $11.78 \%$ for the bark and $79.09 \%$ for the wood (ZAIA; GAMA-RODRIGUES, 2004). Productivity in seven eucalypt hybrids in the State of Pernambuco was on average $88 \mathrm{t} \mathrm{ha}^{-1}$ at 4.5 years of age, at a spacing of $3 \times 2 \mathrm{~m}$, with $70 \%$ of the biomass being allocated to the wood, $13 \%$ to the branches, $9 \%$ to the bark and $8 \%$ to the leaves (ALVES et al., 2007).

In a study monitoring the accumulation of biomass in an age sequence of Eucalyptus grandis planted in the cerrado, Reis et al. (1985) reported that in the initial phase of development of the population (at 15 months), the biomass contained in the wood and bark components was less than $45 \%$ of the total aerial biomass. Over time, the contribution of these components increased, until reaching over $85 \%$ of the total aerial biomass at 73 months. Schumacher, Witschoreck and Calil (2011) also observed that the allocation of wood biomass at 2 years of age, was $47 \%$ of the total biomass, reaching $74.4 \%$ at 8 years. In the same study, it was concluded that the tendency for biomass accumulation in the wood as a function of the age of the trees, when carried out in young forests under 6 years of age, results in a significant loss in timber yield.

It can therefore be seen that the results obtained here are similar to those found in older forests, where the contribution of trunk biomass exceeds $60 \%$ in relation to other compartments of the aerial part of the plant. The allocation of biomass in this study is similar for example, to that found in a study by Alves et al. (2007) in a forest of twice the age (4.5 years), which can be attributed to the fertility of the soil in the present study, and which resulted in good forest growth, reaching an average of $66 \mathrm{t} \mathrm{ha}^{-1}$ aerial biomass at 2.25 years of age.

Leaf biomass in the eucalypt peaked at two years after planting, with around $80 \%$ of the annual increase in biomass being accumulated in the trunk from two years of age on (LACLAU et al., 2010). In tropical and subtropical plantations of eucalypt, a peak in leaf biomass is generally observed at around two years of age (ALMEIDA et al., 2007; DU TOIT, 2008). During the initial phase of development of a tree, a large part of the carbohydrates is channelled into the production of canopy biomass. Later, when the canopies begin to compete with each other, the relative production of the trunk increases and that of the leaves and branches gradually decreases (REIS et al., 1985). The distribution of carbohydrates and the pattern of structural growth of the various components of a tree may be different, depending on factors of soil and climate at the site, on species and planting density (SCHUMACHER; WITSCHORECK; CALIL, 2011). Because of this, it is expected that with increasing age of the forest under study, the percentage allocation of biomass to the leaves should be less than that observed, while for wood, it should increase with decreases in the other components.

Efficiency in the use of leaf nutrients varied between clones (Table 3) for all nutrients. The $\mathrm{C} 2, \mathrm{C} 4$ and C5 clones generally displayed greater values for leaf nutrient use efficiency, as well as greater values for leaf biomass (Table 1) compared to the $\mathrm{C} 1$ and $\mathrm{C} 3$ clones. In absolute terms, $\mathrm{C} 5$ surpasses $\mathrm{C} 2$ and $\mathrm{C} 4$ in the efficient use of $\mathrm{N}$ and $\mathrm{P}$, while $\mathrm{C} 4$ has greater values for the efficient use of $\mathrm{K}, \mathrm{Ca}$ and $\mathrm{Mg}$. It is possible that at a more advanced age, when the competitive effect between plants and the nutrient cycling become more intense, these results become more apparent. The greater demand for nutrients of E. grandis and E. pilularis happens during the period up to canopy closure, after which it levels out (TURNER; LAMBERT, 2008).

According to Zaia and Gama-Rodrigues (2004), levels of $\mathrm{N}, \mathrm{P}, \mathrm{K}, \mathrm{Ca}$ and $\mathrm{Mg}$ in E. grandis at 6 years of age were $1.66,0.09,0.88,0.7$ and 0.25 respectively. For Gonçalves, Raij and Gonçalves (1997), the levels of N, $\mathrm{P}, \mathrm{K}, \mathrm{Ca}$ and $\mathrm{Mg}$ in adult plants is considered adequate when between 1.3 and 1.8, 0.09 and $0.13,0.9$ and 1.3, 0.6 and 1.0 , and 0.35 and $0.50 \%$ respectively. Based on those studies therefore, it can be considered that the results obtained here fall within the range of suitable levels.

In general terms, the tree component with the highest nutrient content is the leaf, while wood has the lowest content; the branches and bark have values considered as intermediate. This tendency towards a greater concentration of most nutrients in the newer structures of the plant is due to the greater metabolic activity of the leaves. Furthermore, it is in these regions that most of the living cells are found, responsible for photosynthesis and transpiration (VIERA, 2012). This tendency was also seen in the present study (Tables 3-5), with the exception of $\mathrm{Ca}$ and $\mathrm{Mg}$ that generally build up in larger amounts in the bark.

The clones also differed in the efficient use of nutrients in the wood (Table 4), displaying the same tendency as seen with the leaves (Table 3).

From a nutritional standpoint, an efficient species is one capable of synthesising the maximum of biomass 
Table 3 - Efficiency in the use of nutrients in the leaves of five clones of Eucalytpus grandis $\mathrm{x}$ E. urophylla, at 2.25 years of age

\begin{tabular}{|c|c|c|c|c|c|}
\hline \multicolumn{6}{|c|}{ Efficiency in the use of nutrients $\left(\mathrm{kg}\right.$ biomass $^{2} \mathrm{~kg}$ nutrient $\left.{ }^{-1}\right)$ in the leaves } \\
\hline Clone & $\mathrm{N}$ & $\mathrm{P}$ & $\mathrm{K}$ & $\mathrm{Ca}$ & $\mathrm{Mg}$ \\
\hline $\mathrm{C} 1$ & 245 (1.66) B & $2733(0.15) b c$ & $409(0.99) b$ & $459(0.89) \mathrm{c}$ & $1235(0.33) \mathrm{bc}$ \\
\hline $\mathrm{C} 2$ & $286(2.02) \mathrm{Ab}$ & $3215(0.18) \mathrm{abc}$ & $635(0.91) \mathrm{a}$ & $746(0.81) \mathrm{abc}$ & $1749(0.33) \mathrm{ab}$ \\
\hline $\mathrm{C} 3$ & $176(1.98) \mathrm{C}$ & $2178(0.16) \mathrm{c}$ & $363(0.96) b$ & $469(0.76) \mathrm{bc}$ & $1049(0.33) \mathrm{c}$ \\
\hline $\mathrm{C} 4$ & $298(2.02) \mathrm{Ab}$ & $3729(0.16) a b$ & $818(0.75) \mathrm{a}$ & $886(0.71) \mathrm{a}$ & $1903(0.33) \mathrm{a}$ \\
\hline C5 & 315 (1.97) A & $4290(0.14) \mathrm{a}$ & $760(0.82) \mathrm{a}$ & $796(0.78) a b$ & $1612(0.39) a b$ \\
\hline $\mathrm{F}$ & $21.5 * *$ & $10.4 * *$ & $21.9 * *$ & $6.6^{* *}$ & $8.4 * *$ \\
\hline $\mathrm{CV} \%$ & 4.8 & 8.1 & 7.6 & 11.7 & 8.3 \\
\hline Mean & 264 & 3229 & 597 & 671 & 1509 \\
\hline
\end{tabular}

Values in parentheses refer to the respective nutrient content (\%) in the leaves. Mean values followed by the same letter in a column do not differ by Tukey's test $(\mathrm{p} \geq 0.05) ;{ }^{* *}$ - significant $(\mathrm{p}<0.01)$ by F-test

Table 4 - Efficiency in the use of nutrients in the wood of five clones of Eucalytpus grandis $\mathrm{x}$ E. urophylla, at 2.25 years of age

\begin{tabular}{lccccc}
\hline \multicolumn{7}{c}{ Efficiency in the use of nutrients $\left(\mathrm{kg}^{2}\right.$ biomass $\left.^{2} \mathrm{~kg}_{\text {nutrient }}{ }^{-1}\right)$ in the wood } \\
\hline Clone & $\mathrm{N}$ & $\mathrm{P}$ & $\mathrm{K}$ & $\mathrm{Ca}$ & $\mathrm{Mg}$ \\
\hline $\mathrm{C} 1$ & $35(0.058) \mathrm{b}$ & $44(0.045) \mathrm{b}$ & $11(0.173) \mathrm{b}$ & $21(0.096) \mathrm{c}$ & $62(0.031) \mathrm{b}$ \\
$\mathrm{C} 2$ & $70(0.059) \mathrm{ab}$ & $87(0.044) \mathrm{a}$ & $20(0.196) \mathrm{a}$ & $95(0.043) \mathrm{a}$ & $180(0.023) \mathrm{a}$ \\
$\mathrm{C} 3$ & $34(0.062) \mathrm{b}$ & $43(0.049) \mathrm{b}$ & $12(0.189) \mathrm{ab}$ & $24(0.091) \mathrm{ab}$ & $63(0.033) \mathrm{b}$ \\
$\mathrm{C} 4$ & $42(0.082) \mathrm{ab}$ & $87(0.040) \mathrm{a}$ & $14(0.242) \mathrm{a}$ & $26(0.133) \mathrm{ab}$ & $77(0.044) \mathrm{b}$ \\
$\mathrm{C} 5$ & $81(0.057) \mathrm{a}$ & $120(0.035) \mathrm{a}$ & $20(0.204) \mathrm{a}$ & $50(0.085) \mathrm{b}$ & $155(0.028) \mathrm{a}$ \\
$\mathrm{F}$ & $5.6^{* *}$ & $17.8^{* *}$ & $8.3^{* *}$ & $46.7^{* *}$ & $17.4^{* *}$ \\
$\mathrm{CV} \%$ & 17.3 & 10.8 & 10.5 & 16.9 & 12.5 \\
Mean & 52 & 76 & 15 & 43 & 107 \\
\hline
\end{tabular}

Values in parentheses refer to the respective nutrient content (\%) in the wood. ${ }^{+}$Values for efficiency divided by 1000 . Mean values followed by the same letter in a column do not differ by Tukey's test $(\mathrm{p} \geq 0.05)$; ** - significant $(\mathrm{p}<0.01)$ by F-test

per absorbed nutrient, so that the smaller the accumulated amount of nutrient in the tree component, the greater the values for the coefficients of biological use. This however has no direct relationship with productivity, as smaller amounts of nutrients do not always imply greater efficiency in production, and may simply represent a lesser capacity for absorbing nutrients from the soil.

The differences in nutrient use efficiency between species, origin, progeny and clone in the eucalypt, besides being inherent to a capacity for the absorption, translocation and conversion of the nutrients into the biomass of each genotype, are products of the interaction of genotype with the environment. Thus, nutrient use efficiency makes it possible to recognise genotypes and management practices that may contribute to sustainability of the forests, since when the efficiency in the use of a nutrient and the expectations for biomass production are known, it becomes possible to estimate the amount of nutrients necessary for a proper nutritional balance during the following cycle (SAIDELLES et al., 2010). That is, more efficient genotypes from the point of view of absorption should be grown in more fertile soils, or receive stronger fertilisation than those with less absorption efficiency. Conversely, genotypes which are highly efficient in converting absorbed nutrients into biomass could be planted in less fertile soil or receive less fertilisation, provided that the levels of available nutrients do not limit growth.

Generally, interspecific eucalypt hybrid clones tend to have a better ability to adapt to different regions, due to combinations of favourable characteristics from their parents, as reported by Alvarez et al. (2006), who found that hybrids of Eucalyptus urophylla $\mathrm{x}$ Eucalyptus grandis used soil phosphorus more efficiently than either of the two parent species. 
Studying the origins of E. grandis and E. saligna at 6.5 years of age, Santana, Barros and Neves (2002) found differences in nutrient use efficiency in the production of trunk biomass, this also varying with the site. Those authors observed that use efficiency decreased in the following order: $\mathrm{P}>\mathrm{Mg}>\mathrm{K}>\mathrm{N}>\mathrm{Ca}$, being the same tendency seen by Faria et al. (2008).

Significant differences for phosphorus use efficiency (PUE) between clones of Eucalyptus urophylla at eight months of age under field conditions were seen by Godoy and Rosado (2011). According to those authors, in addition to the high values found for heritability leading to genetic gains of great magnitude, the selection for PUE of seedlings in the nursery, resulted in the largest values for indirect gains in height for seedlings in the field.

The clones did not differ as to efficiency in the use of nutrients in the branches (Table 5). This result is due in part to the great variability of the data, which can be noted by the high values for the experimental coefficient of variation (CV), possibly determined by the stay of dry branches in the canopy due to the young age of the experiment. The genus Eucalyptus has a good capacity for natural pruning, where shading of the lower branches of the canopy results in their losing physiological activity and being easily eliminated from the plant once dry. This generally occurs in older plantations, however in this experiment, it was seen that some plants still retained dry branches on the trunk, which may have contributed to the results.

The C2, C4 and C5 clones displayed higher values for efficiency in the use of nutrients in the bark, with $\mathrm{C} 5$ being slightly superior, except for $\mathrm{Ca}$ efficiency, where $\mathrm{C} 2$ had higher values. In contrast, $\mathrm{C} 1$ had the lowest values for nutrient use efficiency for this tree component (Table 6).

Table 5 - Efficiency in the use of nutrients in the branches of five clones of Eucalytpus grandis x E. urophylla, at 2.25 years of age

\begin{tabular}{lccccc}
\hline \multicolumn{5}{c}{ Efficiency in the use of nutrients $\left(\mathrm{kg}_{\text {biomass }}^{2} \mathrm{~kg}_{\text {nutrient }}^{-1}\right)$ in the branches } \\
\hline Clone & $\mathrm{N}$ & $\mathrm{P}$ & $\mathrm{K}$ & $\mathrm{Ca}$ & $\mathrm{Mg}$ \\
\hline $\mathrm{C} 1$ & $2612(0.24)$ & $9573(0.07)$ & $1757(0.38)$ & $1514(0.41)$ & $7942(0.09)$ \\
$\mathrm{C} 2$ & $4066(0.15)$ & $7040(0.08)$ & $1822(0.38)$ & $1655(0.34)$ & $6565(0.09)$ \\
$\mathrm{C} 3$ & $3239(0.21)$ & $10230(0.06)$ & $1987(0.34)$ & $1258(0.51)$ & $8037(0.08)$ \\
$\mathrm{C} 4$ & $3271(0.20)$ & $11855(0.06)$ & $1959(0.33)$ & $1511(0.47)$ & $7144(0.09)$ \\
C5 & $3130(0.20)$ & $12019(0.05)$ & $1822(0.34)$ & $1299(0.45)$ & $10208(0.06)$ \\
F & $0.4^{\mathrm{ns}}$ & $1.1^{\mathrm{ns}}$ & $0.1^{\mathrm{ns}}$ & $0.3^{\mathrm{ns}}$ & $0.5^{\mathrm{ns}}$ \\
CV\% & 20.9 & 20.7 & 26.8 & 18.0 & 24.7 \\
Mean & 3264 & 10144 & 1869 & 1447 & 7979 \\
\hline
\end{tabular}

Values in parentheses refer to the respective nutrient content $(\%)$ in the branches. ${ }^{\text {ns }}$ - not significant $(\mathrm{p}<0.01)$ by F-test

Table 6 - Efficiency in the use of nutrients in the bark of five clones of Eucalytpus grandis x E. urophylla, at 2.25 years of age

\begin{tabular}{|c|c|c|c|c|c|}
\hline \multicolumn{6}{|c|}{ Efficiency in the use of nutrients $\left(\mathrm{kg}\right.$ biomass $^{2} \mathrm{~kg}$ nutrient $\left.{ }^{-1}\right)$ in the bark } \\
\hline Clone & $\mathrm{N}$ & $\mathrm{P}$ & $\mathrm{K}$ & $\mathrm{Ca}$ & $\mathrm{Mg}$ \\
\hline $\mathrm{C} 1$ & $787(0.27) \mathrm{c}$ & $2234(0.09) \mathrm{c}$ & $457(0.47) b$ & $113(1.89) b$ & $555(0.38) \mathrm{d}$ \\
\hline $\mathrm{C} 2$ & $2501(0.23) \mathrm{a}$ & $9347(0.06) \mathrm{a}$ & $898(0.66)$ a & $495(1.25) \mathrm{a}$ & $1758(0.33) b$ \\
\hline $\mathrm{C} 3$ & $1435(0.23) b c$ & $3725(0.09) b c$ & $781(0.42) a b$ & $204(1.67) b$ & $1027(0.33) \mathrm{c}$ \\
\hline $\mathrm{C} 4$ & $2406(0.22) \mathrm{ab}$ & $6609(0.08) a b$ & $938(0.56) \mathrm{a}$ & $371(1.42) \mathrm{a}$ & 1339 (0.39) bc \\
\hline C5 & $3155(0.18) \mathrm{a}$ & $9924(0.06) \mathrm{a}$ & $967(0.58) \mathrm{a}$ & $423(1.31) \mathrm{a}$ & $2460(0.23) \mathrm{a}$ \\
\hline $\mathrm{F}$ & $20.9 * *$ & $23.0 * *$ & $8.1 * *$ & $28.5 * *$ & $38.6^{* *}$ \\
\hline $\mathrm{CV} \%$ & 11.1 & 12.3 & 10.0 & 10.3 & 8.7 \\
\hline Mean & 2057 & 6368 & 808 & 321 & 1428 \\
\hline
\end{tabular}

Values in parentheses refer to the respective nutrient content (\%) in the bark. Mean values followed by the same letter in a column do not differ by Tukey's test $(\mathrm{p} \geq 0.05)$; $* *$ - significant $(\mathrm{p}<0.01)$ by F-test 
The harvest and removal from the site of only the commercial parts of the plant is recommended as a way of reducing the export of nutrients from the system, thereby maintaining the quality and productivity of the soil. Thus, with the production of coal and pulp, and for other uses, it is recommended to debark the trunk and leave the bark in the forest, reducing the removal of nutrients, especially of $\mathrm{Ca}$, which by not being internally remobilised by the eucalypt, tends to concentrate in greater quantities in the bark (ARIAS et al., 2011). In this way, genotypes which are efficient in the use of $\mathrm{Ca}$, such as $\mathrm{C5}$, which stood out as most efficient in the use of nutrients in the bark, are important for maintaining the productivity of forest sites, as they contribute to a reduction in the export of $\mathrm{Ca}$, and economy in the use of the nutrient (PINTO et al., 2011).

This is also true for $\mathrm{Mg}$ and to a lesser extent for the remaining nutrients, which due to displaying greater mobility in the plant are found in greater percentages and amounts in other components, such as leaves and branches. In terms of nutrient content, the wood has the lowest associated values, but being the most abundant component of the tree, it is responsible for the largest export of nutrients from the system. In this respect, Santana et al. (2008) found that with an increase in age, nutrients allocated to the canopy tend to reduce and nutrients allocated to the trunk tend to increase.

In view of the above, the use of genotypes efficient in the use of nutrients is essential for sustainability of the forest ecosystem, reducing the export of nutrients in proportion to the biomass produced. This becomes more important depending on the use of some forests, such as those intended for pellet production, where the complete tree is harvested, including the bark and the canopy. Also, the recommendation of genotypes which are efficient in the use of nutrients for sites of poor soil fertility can optimise productivity in these locations, without requiring major applications of fertiliser.

\section{CONCLUSIONS}

1. The clones differ as to the production and allocation of biomass, and the efficient use of nutrients in the various compartments of the aerial part of the tree, but there is no genotype with a superior performance in all of these characteristics;

2. In general, the $\mathrm{C} 2, \mathrm{C} 4$ and especially the $\mathrm{C} 5$ clones, are superior to $\mathrm{C} 1$ and $\mathrm{C} 3$ in the production of biomass and efficiency in the use of the nutrients in different compartments of the aerial part of the tree, and may be used as promising alternatives in the development of forest breeding programs for areas with limited nutrients.

\section{REFERENCES}

ALMEIDA, A. C. et al. Growth and water balance of Eucalyptus grandis hybrid plantations in Brazil during a rotation for pulp production. Forest Ecology and Management, v. 251, p. 10-21, 2007.

ALVAREZ, V. F. C. et al. Improving phosphorus availability from Patos phosphate rock for eucalyptus: a study with 32P radiotracer. Scientia Agricola, v. 63, p. 65-69, 2006.

ALVES, A. M. C. et al. Quantificação da produção de biomassa em clones de eucaliptos com 4,5 anos, no Polo Gesseiro de Araripe-PE. Revista de Ciências Agrárias, n. 48, p. 161-173, 2007.

ARIAS, D. et al. Productivity, aboveground biomass, nutrient uptake and carbon content in fast-growing tree plantations of native and introduced species in the Southern Region of Costa Rica. Biomass and Bioenergy, v. 35, p. 1779-1788, 2011.

Du TOIT, B. Effects of site management on growth, biomass partitioning and light use efficiency in a young stand of Eucalyptus grandis in South Africa. Forest Ecology and Management, v. 255, p. 2324-2336, 2008.

FARIA, G. E. et al. Avaliação da produtividade, conteúdo e eficiência de utilização de nutrientes em genótipos de Eucalyptus spp. no Vale do Jequitinhonha, MG. Ciência Florestal, v. 18, n. 3, p. 363-373, 2008.

FERREIRA, D. F. Análises estatísticas por meio do SISVAR para Windows versão 4.0. In: REUNIÃO ANUAL DA REGIÃO BRASILEIRA DA SOCIEDADE INTERNACIONAL DE BIOMETRIA, 45., 2000, São Carlos. Resumos... São Carlos: UFSCar, 2000. p. 255-258.

FOOD AND AGRICULTURE ORGANIZATION. How to feed the world in 2050, 2010. Disponível em: <http://www.fao.org/ fileadmin/templates/wsfs/docs/expert_paper/How_to_Feed the_World_in_2050.pdf >.Acesso em: 15 mai. 2013.

GODOY, T. G.; ROSADO, C. S. Efficiency of phosphorus use in young plants of Eucalyptus urophylla S. T. Blake. Revista Cerne, v. 17, n. 3, p. 303-308, 2011.

GONÇALVES, J. L. M.; RAIJ, B. V.; GONÇALVES, J. Q. Florestas. In: RAIJ, B. V. et al. Recomendações de adubação e calagem para o Estado de São Paulo. 2 ed. Campinas: Instituto Agronômico: Fundação IAC, 1997. p. 247-259. (Boletim Técnico, 100).

INDÚSTRIA BRASILIERA DE ÁRVORES. Relatório Ibá 2015. Brasília, DF, 2015. 62 p. Disponível em: < http://www. iba.org/images/shared/iba_2015.pdf >. Acesso em: 30 jul. 2015 .

LACLAU, J. et al. Biogeochemical cycles of nutrients in tropical Eucalyptus plantations: main features shown by intensive monitoring in Congo and Brazil. Forest Ecology and Management, v. 259, p. 1771-1785, 2010. 
MALAVOLTA, E. A.; VITTI, G. C.; OLIVEIRA, S. A. Avaliação do estado nutricional das plantas: princípios e aplicações. 2. ed. Piracicaba: Potafós, 1997. 304 p.

MENDES, H. S. J. et al. Respostas fisiológicas de genótipos de Eucalyptus grandis $x$ E. urophylla à disponibilidade hídrica e adubação potássica. Revista Cerne, v. 19, p. 603$611,2013$.

PARENTONI, S. N.; MENDES, F. F.; GUIMARÃES, L. J. M. Melhoramento para eficiência no uso de fósforo. In: FRITSCHENETO, R.; BORÉM, A. (Ed.). Melhoramento de plantas para condições de estresses abióticos. Visconde do Rio Branco: Suprema, 2011. p. 101-126.

PINTO, S. I. C. et al. Eficiência nutricional de clones de eucalipto na fase de mudas cultivadas em solução nutritiva. Revista Brasileira de Ciência do Solo, v. 35, p. 523-533, 2011.

REIS, M. G. F. et al. Acúmulo de biomassa em uma sequência de idade de Eucalyptus grandis plantado no Cerrado, em duas áreas com diferentes produtividades. Revista Árvore, v. 9, n. 2, p. 149-162, 1985.

SAIDELLES, F. L. F. et al. Determinação do ponto de amostragem para a quantificação de macronutrientes em Acacia mearnsii de Wild. Floresta, v. 40, n. 1, p. 49-62, 2010.

SANTANA, R. C. et al. Alocação de nutrientes em plantios de eucalipto no Brasil. Revista Brasileira de Ciência do Solo, p. 2724-2734, 2008. Número especial.

SANTANA, R. C.; BARROS, N. F.; NEVES, J. C. L. Eficiência de utilização de nutrientes e sustentabilidade da produção em procedências de Eucalyptus grandis e Eucalyptus saligna em sítios florestais do estado de São Paulo. Revista Árvore, v. 26, n. 4, p. 447-457, 2002.

SCHUMACHER, M. V.; WITSCHORECK, R.; CALIL, F. N. Biomassa em povoamentos de Eucalyptus spp. de pequenas propriedades rurais em Vera Cruz, RS. Ciência Florestal, v. 21, n. 1, p. 17-22, 2011.
SIDDIQI, M. Y.; GLASS, A. D. M. Utilization index: a modified approach to the estimation and comparison of nutrient utilization efficiency in plants. Journal of Plant Nutrition, v. 4, p. 289302, 1981.

SILVA, H. M. et al. Fertilizer management of eucalypt plantations on sandy soil in Brazil: initial growth and nutrient cycling. Forest Ecology and Management, v. 301, p.67-78, 2013. Disponível em: <http://dx.doi.org/10.1016/ j.foreco.2012.10.033.>. Acesso em: 15 out. 2013.

SOARES, C. P. B.; PAULA NETO, F.; SOUZA, A. L. Dendrometria e inventário florestal. Viçosa, MG: UFV, 2006. $276 \mathrm{p}$.

SOUSA NETO, E. L. et al. Atributos físicos do solo e produtividade de milho em resposta a culturas de pré-safra. Pesquisa Agropecuária Brasileira, v. 43, n. 2, p. 255-260, 2008.

STAPE, J. L.; BINKLEY, D.; RYAN, M. G. Eucalyptus production and the supply, use and efficiency of use of water, light and nitrogen across a geographic gradient in Brazil. Forest Ecology and Management, n. 193, p. 17-31, 2004.

TURNER, J.; LAMBERT, M. J. Nutrient cycling in ages sequences of two Eucalyptus plantation species. Forest Ecology and Management, n. 255, p. 1701-1712, 2008.

VIERA, M. Dinâmica nutricional em um povoamento híbrido de Eucalyptus urophylla $\mathrm{x}$ Eucalyptus globulus em Eldorado do Sul - RS, Brasil. 2012. 119 f. Tese (Doutorado em Engenharia Florestal: Área de Concentração em Silvicultura) - Universidade Federal de Santa Maria, Centro de Ciências Rurais, Santa Maria, 2012.

VITAL, B. R. Métodos de determinação da densidade da madeira. Viçosa, MG: Sociedade de Investigações Florestais, 1984. 21 p. (Boletim Técnico, 1).

ZAIA, F. C.; GAMA-RODRIGUES, A. C. Ciclagem e balanço de nutrientes em povoamentos de eucalipto na região Norte Fluminense. Revista Brasileira de Ciências do Solo, v. 28, p. 843-852, 2004. 